\title{
Variation in Fruit and Seed Traits among Different Seed Sources of Calophyllum inophyllum L. Collected from Coastal Regions of Konkan, India
}

\author{
Rahul Sreekumar" and Rajesh P. Gunaga
}

\author{
College of Forestry, ACHF, Navsari Agricultural University, Navsari, Gujarat, India \\ *Corresponding author
}

\begin{abstract}
Keywords
Seed Source,

Calophyllum

inophyllum, Seed

traits, Variation.

Article Info

Accepted:

07 October 2017

Available Online:

10 December 2017 sources of Calophyllum inophyllum collected from the coastal regions of Konkan (four locations from Maharashtra and one location from Karnataka). Fruits collected from each accession were evaluated for various fruit and seed traits viz. fruit length, fruit width, fruit weight, seed length, seed width, seed weight, seed volume, seed density, shell weight, kernel weight and shell to kernel ratio. It was observed that all the 15 seed sources showed a wide range of variation in fruit length (16.60 to $64.03 \mathrm{~mm}$ ), fruit width (12.10 to 36.14 $\mathrm{mm}$ ) and fruit weight (2.40 to $18.66 \mathrm{~g}$ ) in collected seedlots. Fruits collected from $\mathrm{CIMP}_{1}$, $\mathrm{CIMP}_{4}, \mathrm{CIMN}_{1}, \mathrm{CIMN}_{2}$ and $\mathrm{CIMN}_{3}$ recorded to be bolder and bigger in size than other seed sources. Significant difference was observed among the seed sources for all seed traits, except seed width. Accession $\mathrm{CIMP}_{1}$ showed highest value for most of the seed traits, followed by $\mathrm{CIMD}_{3}, \mathrm{CIMP}_{4}, \mathrm{CIMN}_{1}$ and $\mathrm{CIMN}_{3}$ seed sources. Kernel weight ranged from 2.28 to $5.06 \mathrm{~g}$, whereas shell weight varied between 1.13 and $2.88 \mathrm{~g}$ with an overall shell to kernel ratio ranging from 0.42 to 0.63 . Considering growing condition, seeds collected from Maharashtra sources showed bigger and bolder seeds than Karnataka seed source.
\end{abstract}

\section{A B S T R A C T}

The present study was carried out in the College of Forestry, ACHF, Navsari Agricultural University during 2015 to understand the variation in fruit and seed traits among 15 seed

\section{Introduction}

Morphological variations in fruit/pod and seed characteristics among the natural population are useful in selection programme for genetic improvement of forest species (Bahadur and Hooda, 1995; Kaushik et al., 2007). For screening the naturally available genetic variations to select the best planting material for attaining higher productivity, source variation tests are very much necessary (Bhat and Chauhan, 2002). Such tests can yield valuable information that may be useful for commercial planters, nursery growers, foresters and tree breeders. Fruit and seed variability can be linked to the genetic potential of a genotype (Pavithra et al., 2013). Understanding intra and inter population variation for reproductive traits would be fundamental steps for domestication. Information generated through such studies help in further selection and multiplication of high yielding genotypes. Considering the genetic quality of seeds, the Australian Tree Seed Centre has adopted the slogan- 'Good seed does not cost - it pays' (Midgley, 1996) to provide higher productivity, which means that the small investment for obtaining best seed source is meagre that produce better growth of the progeny, which ultimately 
achieve the higher yield (Schmidt, 2000). Therefore, it is very important to select superior trees, which are morphological superior in terms of its commercial characters and free from pest and diseases. Seed collection could be done on such trees for large-scale seedling production. Efforts have already been made in some commercial important species; however, such information is scanty in many forest species and Calophyllum inophyllum is one among them, which is an important bio-resource used in biofuel production.

Calophyllum inophyllum L. (Clusiaceae; popularly called Undi), is a littoral tree distributed along the coastal lines of India, except Gujarat. It is considered as a multipurpose tree species due to its various end uses like biofuel, seed oil, small timber, fuel wood, medicinal value and others (Friday and Okano, 2006). The seed (kernel) yields 36 to 80 per cent non-edible oil (Rahul, 2016), and it can be used in the conventional diesel engines (without any alterations) in its pure form or as a blend with mineral oil; moreover, seed oil of Undi fulfils the quality of fossil fuel as per American Standards for Testing and Material (ASTM) - 6751 (Agarwal, 2007; Chavan et al., 2013). Therefore, there is a wide scope for improvement of this species towards biofuel production. With this, an attempt has been made to study the variability in fruit and seed traits among few selected accessions of $C$. inophyllum, an important forest resource of coastal regions in India.

\section{Materials and Methods}

The present study was carried out in the laboratory of College of Forestry, Navsari Agricultural University, Navsari during 2015. Fifteen high fruit yielding phenotypes of $C$. inophyllum were selected as seed source in five locations from Konkan region of India, which includes four locations viz., Dapoli,
Navare, Purnagharh and Vettye from Maharashtra and one location, i.e., Kumta from Karnataka (Table 1). Matured fruits were collected from these selected 15 trees and were measured for various fruit and seed traits. From each source $(\mathrm{N}=60)$, three samples were drawn randomly and from each sample, twenty seeds were selected for measurement of fruit length, fruit thickness, fruit weight, seed length, seed thickness, seed weight, seed volume and seed density.

However, for assessment of shell weight, kernel weight and shell: kernel ratio, 30 seeds were cut and used for measurement. Data was subjected to statistical analysis and ANOVA table was constructed. Values of minimum, maximum, mean, standard deviation, standard error of mean and critical difference at $5 \% \mathrm{P}$ were given in tabular form and detailed inference is described below.

\section{Results and Discussion}

\section{Fruit characteristics}

Fifteen seed sources of $C$. inophyllum showed a wide range of variation in fruit length (16.60 to $64.03 \mathrm{~mm}$ ), fruit width (12.10 to 36.14 $\mathrm{mm}$ ) and fruit weight (2.40 to $18.66 \mathrm{~g}$ ) in collected seedlots. Significant difference for these parameters was recorded among studied seed sources (Table 2).

Mean values shows that fruit length varied between $23.31\left(\mathrm{CIMV}_{2}\right)$ and $34.50 \mathrm{~mm}$ $\left(\mathrm{CIMP}_{1}\right)$ with mean of $28.73 \mathrm{~mm}$. In case of fruit width and fruit weight, the mean values ranged from $21.51\left(\mathrm{CIKK}_{3}\right)$ to $31.21 \mathrm{~mm}$ $\left(\mathrm{CIMN}_{1}\right)$ and $5.74\left(\mathrm{CIMV}_{2}\right)$ to $13.82 \mathrm{~g}$ $\left(\mathrm{CIMN}_{1}\right)$, respectively. Accession $\mathrm{CIMN}_{1}$ showed highest value for both fruit width $(36.14 \mathrm{~mm})$ and fruit weight $(18.66 \mathrm{~g})$. Fruits collected from CIMP $1, \mathrm{CIMP}_{4}, \mathrm{CIMN}_{1}$ to $\mathrm{N}_{3}$ recorded to be bolder and bigger in size than other seed sources. 


\section{Seed characteristics}

Based on raw data, seed length (14.51 to $34.82 \mathrm{~mm}$ ), seed width (13.05 to $33.04 \mathrm{~mm}$ ), seed weight (0.61 to $9.97 \mathrm{~g}$ ), seed volume $\left(1.38\right.$ to $\left.14.34 \mathrm{~cm}^{3}\right)$ and seed density ( 0.010 to $1.187 \mathrm{~g} / \mathrm{cm}^{3}$ ) showed lot of difference in collected seedlots of $C$. inophyllum.

Analyzed data showed that there was a significant difference among the 15 seed sources collected across the Konkan region for all seed traits, except seed width. Mean seed length ranged from 22.27 to $30.16 \mathrm{~mm}$, whereas seed weight ranged from 3.57 to 7.02 $\mathrm{g}$ and seed volume ranged between 4.61 and $9.76 \mathrm{~cm}^{3}$ with seed density values of 0.723 to $0.928 \mathrm{~g} / \mathrm{cm}^{3}$ among studied seed sources (Table 3). Accession CIMP 1 showed highest value for most of the seed traits, followed by $\mathrm{CIMD}_{3}, \mathrm{CIMP}_{4}, \mathrm{CIMN}_{1}$ and $\mathrm{CIMN}_{3}$ seed sources. Considering growing condition, seeds collected from Maharashtra sources showed bigger and bolder seeds than Karnataka seed source.

Seed kernel of $C$. inophyllum is used for both oil extraction as well as seed germination. In the present study, kernel weight ranged from $2.28\left(\mathrm{CIMV}_{2}\right)$ to $5.06 \mathrm{~g}\left(\mathrm{CIMP}_{1}\right)$ with mean of $3.35 \mathrm{~g}$, whereas shell weight ranged from $1.13\left(\mathrm{CIMV}_{1}\right)$ to $2.88 \mathrm{~g}\left(\mathrm{CIMN}_{1}\right.$; Fig. 1$)$.

The overall shell to kernel ratio varied between 0.42 and 0.63 .
Seeds are unique in natural regeneration and propagation because seeds constitute unique genetic composition resulting from mixing parental genetic materials, which result in genetic variation of the offspring that enhances the ecological adaptability of species (Schmidt, 2000). Therefore, understanding intra and inter population variation for reproductive traits would be essential for popularization of species. This also helps in further selection and improvement of species for commercial traits to obtain higher yield. It is also reported that seed germination and seedling vigour are affected by seed size and other factors like dormancy, moisture, etc. (Schmidt, 2000). For instance, the study conducted by Gunaga (2011) showed that bigger sized seeds of $C$. inophyllum produced quick, uniform and maximum germination as well as vigourous seedling and higher dry biomass as compared to those of medium and small sized seeds. Genetic quality seeds are essential for production of quality seedlings in large quantities. In the present study, variation in different fruit and seed traits has been recorded among 15 genotypes of $C$. inophyllum (Table 2 and 3). Hathurusingha et al., (2011) compared various seed traits among $C$. inophyllum of Yeppoon, Australia with Meegoda western province of Sri Lanka. It was recorded that seeds collected from Yeppoon source had higher kernel weights $\left(2988.0 \mathrm{~kg} \mathrm{ha}^{-1} \mathrm{a}^{-1}\right)$ as compared to Meegoda source.

Table.1 Details of location including geo-coordinates of selected accessions of Calophyllum inophyllum

\begin{tabular}{|l|l|c|c|l|}
\hline \multirow{2}{*}{$\begin{array}{l}\text { Name of the } \\
\text { location }\end{array}$} & \multirow{2}{*}{ State } & \multicolumn{2}{|c|}{ Geo-coordinates } & \multirow{2}{*}{ Accessions selected } \\
\cline { 3 - 5 } & & Latitude (N) & Longitude (E) & \\
\hline Dapoli & Maharashtra & $17^{\circ} 48^{\prime} 12^{\prime \prime}$ & $73^{\circ} 06^{\prime} 10^{\prime \prime}$ & $\mathrm{CIMD}_{1}, \mathrm{CIMD}_{2}, \mathrm{CIMD}_{3}$ \\
\hline Navare & Maharashtra & $17^{\circ} 06^{\prime} 43^{\prime \prime}$ & $73^{\circ} 16^{\prime} 29^{\prime \prime}$ & $\mathrm{CIMN}_{1}, \mathrm{CIMN}_{2}, \mathrm{CIMN}_{3}$, \\
\hline Purnagharh & Maharashtra & $16^{\circ} 48^{\prime} 19^{\prime \prime}$ & $73^{\circ} 19^{\prime} 08^{\prime \prime}$ & $\mathrm{CIMP}_{1}, \mathrm{CIMP}_{2}, \mathrm{CIMP}_{3}, \mathrm{CIMP}_{4}$ \\
\hline Vettye & Maharashtra & $16^{\circ} 41^{\prime} 17^{\prime \prime}$ & $73^{\circ} 19^{\prime} 52^{\prime \prime}$ & $\mathrm{CIMV}_{1}, \mathrm{CIMV}_{2}$ \\
\hline Kumta & Karnataka & $14^{\circ} 25^{\prime} 39^{\prime \prime}$ & $74^{\circ} 23^{\prime} 10^{\prime \prime}$ & $\mathrm{CIKK}_{1}, \mathrm{CIKK}_{2}, \mathrm{CIKK}_{3}$ \\
\hline
\end{tabular}


Table.2 Variation in fruit traits among 15 different accessions of Calophyllum inophyllum

\begin{tabular}{|c|c|c|c|c|c|c|c|c|c|c|c|c|}
\hline \multirow[t]{2}{*}{ Accession No. } & \multicolumn{4}{|c|}{ Fruit length (mm) } & \multicolumn{4}{|c|}{ Fruit width (mm) } & \multicolumn{4}{|c|}{ Fruit weight (gm) } \\
\hline & Min & Max & Mean & SD & Min & Max & Mean & SD & Min & Max & Mean & SD \\
\hline $\mathrm{CIMV}_{1}$ & 16.60 & 31.58 & 24.42 & 2.59 & 17.83 & 30.69 & 23.80 & 2.28 & 2.40 & 12.66 & 6.69 & 2.03 \\
\hline $\mathrm{CIMV}_{2}$ & 18.95 & 26.16 & 23.31 & 1.47 & 18.38 & 25.45 & 22.88 & 1.39 & 3.27 & 7.54 & 5.74 & 0.88 \\
\hline $\mathrm{CIMD}_{1}$ & 23.30 & 33.35 & 27.65 & 2.62 & 21.11 & 28.02 & 24.61 & 1.93 & 3.98 & 12.02 & 8.03 & 1.70 \\
\hline $\mathrm{CIMD}_{2}$ & 25.32 & 33.12 & 29.28 & 2.10 & 20.73 & 29.95 & 25.77 & 1.87 & 5.81 & 12.73 & 8.78 & 1.61 \\
\hline $\mathrm{CIMD}_{3}$ & 25.80 & 37.41 & 31.22 & 2.48 & 22.56 & 31.39 & 25.88 & 1.94 & 6.36 & 14.18 & 9.36 & 1.80 \\
\hline $\mathrm{CIMP}_{1}$ & 23.31 & 40.00 & 34.50 & 3.05 & 21.27 & 33.90 & 30.16 & 2.72 & 5.24 & 18.50 & 13.18 & 2.81 \\
\hline $\mathrm{CIMP}_{2}$ & 19.45 & 41.67 & 29.51 & 4.04 & 18.24 & 31.66 & 25.77 & 3.06 & 3.03 & 17.29 & 9.82 & 3.22 \\
\hline $\mathrm{CIMP}_{3}$ & 24.18 & 33.82 & 28.63 & 2.27 & 20.39 & 29.11 & 24.79 & 2.08 & 4.82 & 11.50 & 7.77 & 1.62 \\
\hline $\mathrm{CIMP}_{4}$ & 26.13 & 64.03 & 31.27 & 5.29 & 23.01 & 31.43 & 26.41 & 1.88 & 5.97 & 15.18 & 9.48 & 2.00 \\
\hline $\mathrm{CIMN}_{1}$ & 28.36 & 38.84 & 33.83 & 2.18 & 27.61 & 36.14 & 31.21 & 1.76 & 9.49 & 18.66 & 13.82 & 2.05 \\
\hline $\mathrm{CIMN}_{2}$ & 17.81 & 36.73 & 30.26 & 4.10 & 17.66 & 31.94 & 27.19 & 3.16 & 2.49 & 14.37 & 10.04 & 2.82 \\
\hline $\mathrm{CIMN}_{3}$ & 22.51 & 42.46 & 31.90 & 3.74 & 22.05 & 32.12 & 28.05 & 2.52 & 5.22 & 17.55 & 11.83 & 2.79 \\
\hline $\mathrm{CIKK}_{1}$ & 18.01 & 37.25 & 24.76 & 3.39 & 17.23 & 28.39 & 21.59 & 2.45 & 2.91 & 12.55 & 6.17 & 2.03 \\
\hline $\mathrm{CIKK}_{2}$ & 19.43 & 30.45 & 26.12 & 2.73 & 16.03 & 26.53 & 22.04 & 2.16 & 2.67 & 8.92 & 5.86 & 1.79 \\
\hline $\mathrm{CIKK}_{3}$ & 17.39 & 30.78 & 24.35 & 2.66 & 12.10 & 26.32 & 21.51 & 2.69 & 3.82 & 11.47 & 8.49 & 1.94 \\
\hline Mean & - & - & 28.73 & 2.98 & - & - & 25.44 & 2.26 & - & - & 9.00 & 2.07 \\
\hline $\operatorname{SEm}( \pm)$ & - & - & 0.65 & - & - & - & 0.51 & - & - & - & 0.73 & - \\
\hline CD@ $5 \% \mathbf{P}$ & - & - & 1.87 & - & - & - & 1.47 & - & - & - & 2.10 & - \\
\hline
\end{tabular}


Table.3 Variation in seed traits among 15 different accessions of Calophyllum inophyllum

\begin{tabular}{|c|c|c|c|c|c|c|c|c|c|c|c|c|c|c|c|c|c|c|c|c|}
\hline \multirow[t]{2}{*}{ Accession No. } & \multicolumn{4}{|c|}{ Seed length $(\mathrm{mm})$} & \multicolumn{4}{|c|}{ Seed width $(\mathrm{mm})$} & \multicolumn{4}{|c|}{ Seed weight (g) } & \multicolumn{4}{|c|}{ Seed volume $\left(\mathrm{cm}^{3}\right)$} & \multicolumn{4}{|c|}{ Seed density (g/cc) } \\
\hline & Min & Max & Mean & SD & Min & Max & Mean & SD & Min & Max & Mean & SD & Min & Max & Mean & SD & Min & Max & Mean & SD \\
\hline $\mathrm{CIMV}_{1}$ & 14.70 & 28.88 & 22.32 & 2.52 & 13.62 & 24.91 & 20.04 & 2.04 & 0.85 & 6.91 & 3.59 & 1.20 & 1.38 & 9.23 & 4.61 & 1.48 & 0.243 & 0.900 & 0.782 & 0.125 \\
\hline $\mathrm{CIMV}_{2}$ & 18.12 & 25.11 & 22.27 & 1.40 & 16.41 & 22.64 & 20.44 & 1.21 & 1.70 & 4.87 & 3.57 & 0.65 & 2.39 & 6.38 & 4.66 & 0.80 & 0.288 & 0.869 & 0.771 & 0.095 \\
\hline CIMD $_{1}$ & 20.59 & 29.81 & 25.06 & 2.04 & 17.91 & 25.35 & 21.72 & 1.63 & 1.16 & 6.81 & 4.54 & 1.08 & 3.30 & 9.33 & 5.98 & 1.33 & 0.272 & 0.873 & 0.764 & 0.106 \\
\hline CIMD $_{2}$ & 21.23 & 30.75 & 25.65 & 1.91 & 17.70 & 27.27 & 22.00 & 1.76 & 3.01 & 7.65 & 4.82 & 1.00 & 3.47 & 9.31 & 6.34 & 1.33 & 0.618 & 1.023 & 0.763 & 0.064 \\
\hline $\mathrm{CIMD}_{3}$ & 23.82 & 33.08 & 28.00 & 2.16 & 19.94 & 27.66 & 23.43 & 1.77 & 3.37 & 8.37 & 5.78 & 1.12 & 4.46 & 12.08 & 7.51 & 1.63 & 0.632 & 0.890 & 0.774 & 0.052 \\
\hline $\mathrm{CIMP}_{1}$ & 20.68 & 34.82 & 30.16 & 2.66 & 18.06 & 29.36 & 25.42 & 2.13 & 2.15 & 9.96 & 7.02 & 1.84 & 3.21 & 14.34 & 9.76 & 2.23 & 0.226 & 0.905 & 0.723 & 0.108 \\
\hline $\mathrm{CIMP}_{2}$ & 17.33 & 31.63 & 25.26 & 3.08 & 13.86 & 25.86 & 21.20 & 2.96 & 0.64 & 8.13 & 4.57 & 1.76 & 1.58 & 10.07 & 5.83 & 2.20 & 0.328 & 0.994 & 0.782 & 0.150 \\
\hline $\mathrm{CIMP}_{3}$ & 20.10 & 30.32 & 24.95 & 2.19 & 17.82 & 25.58 & 21.33 & 1.88 & 2.40 & 7.32 & 4.22 & 1.00 & 3.25 & 9.57 & 5.73 & 1.45 & 0.487 & 0.847 & 0.742 & 0.059 \\
\hline $\mathrm{CIMP}_{4}$ & 22.89 & 31.56 & 26.78 & 2.21 & 19.71 & 33.04 & 22.71 & 2.26 & 2.33 & 7.99 & 5.25 & 1.19 & 4.23 & 10.56 & 6.78 & 1.60 & $\mathbf{0 . 0 1 0}$ & 0.957 & 0.761 & 0.134 \\
\hline CIMN $_{1}$ & 22.89 & 31.56 & 26.78 & 2.21 & 19.71 & 33.04 & 22.71 & 2.26 & 2.33 & 7.99 & 5.25 & 1.19 & 4.23 & 10.56 & 6.78 & 1.60 & 0.010 & 0.957 & 0.761 & 0.134 \\
\hline $\mathrm{CIMN}_{2}$ & 14.51 & 30.01 & 25.56 & 3.49 & 13.60 & 25.01 & 21.86 & 2.71 & 0.61 & 6.91 & 4.71 & 1.49 & 1.39 & 9.42 & 6.25 & 1.95 & 0.420 & 0.920 & 0.760 & 0.075 \\
\hline $\mathrm{CIMN}_{3}$ & 18.89 & 31.83 & 26.67 & 2.88 & 16.66 & 26.00 & 22.65 & 2.09 & 2.24 & 7.51 & 5.41 & 1.17 & 2.56 & 10.30 & 6.89 & 1.74 & 0.695 & 0.937 & 0.795 & 0.052 \\
\hline $\mathrm{CIKK}_{1}$ & 17.07 & 34.20 & 24.75 & 3.22 & 14.92 & 27.14 & 20.97 & 2.43 & 2.12 & 9.97 & 5.08 & 1.61 & 2.09 & 11.42 & 5.62 & 1.96 & 0.753 & 1.032 & 0.913 & 0.055 \\
\hline $\mathrm{CIKK}_{2}$ & 18.40 & 28.80 & 24.55 & 2.53 & 13.05 & 24.53 & 20.11 & 2.02 & 1.73 & 7.29 & 4.07 & 1.13 & 2.17 & 8.11 & 5.03 & 1.37 & 0.440 & 1.039 & 0.817 & 0.102 \\
\hline $\mathrm{CIKK}_{3}$ & 19.14 & 31.58 & 24.62 & 2.43 & 15.16 & 25.48 & 20.96 & 1.98 & 1.92 & 7.40 & 5.27 & 1.17 & 2.41 & 9.79 & 5.75 & 1.46 & 0.606 & 1.187 & 0.928 & 0.110 \\
\hline Mean & - & - & 25.56 & 2.46 & - & - & 21.84 & 2.08 & - & - & 4.88 & 1.24 & - & - & 6.23 & 1.61 & - & - & 0.789 & 0.095 \\
\hline SEm ( $( \pm)$ & - & - & 0.77 & - & - & - & 1.70 & - & - & - & 0.34 & - & - & - & 0.46 & - & - & - & 0.01 & - \\
\hline CD@ $5 \% \mathbf{P}$ & - & - & 2.22 & - & - & - & NS & - & - & - & 0.98 & - & - & - & 1.32 & - & - & - & 0.03 & - \\
\hline
\end{tabular}


Fig.1 Variation in shell weight, kernel weight and shell to kernel ratio among 15 different accessions of Calophyllum inophyllum

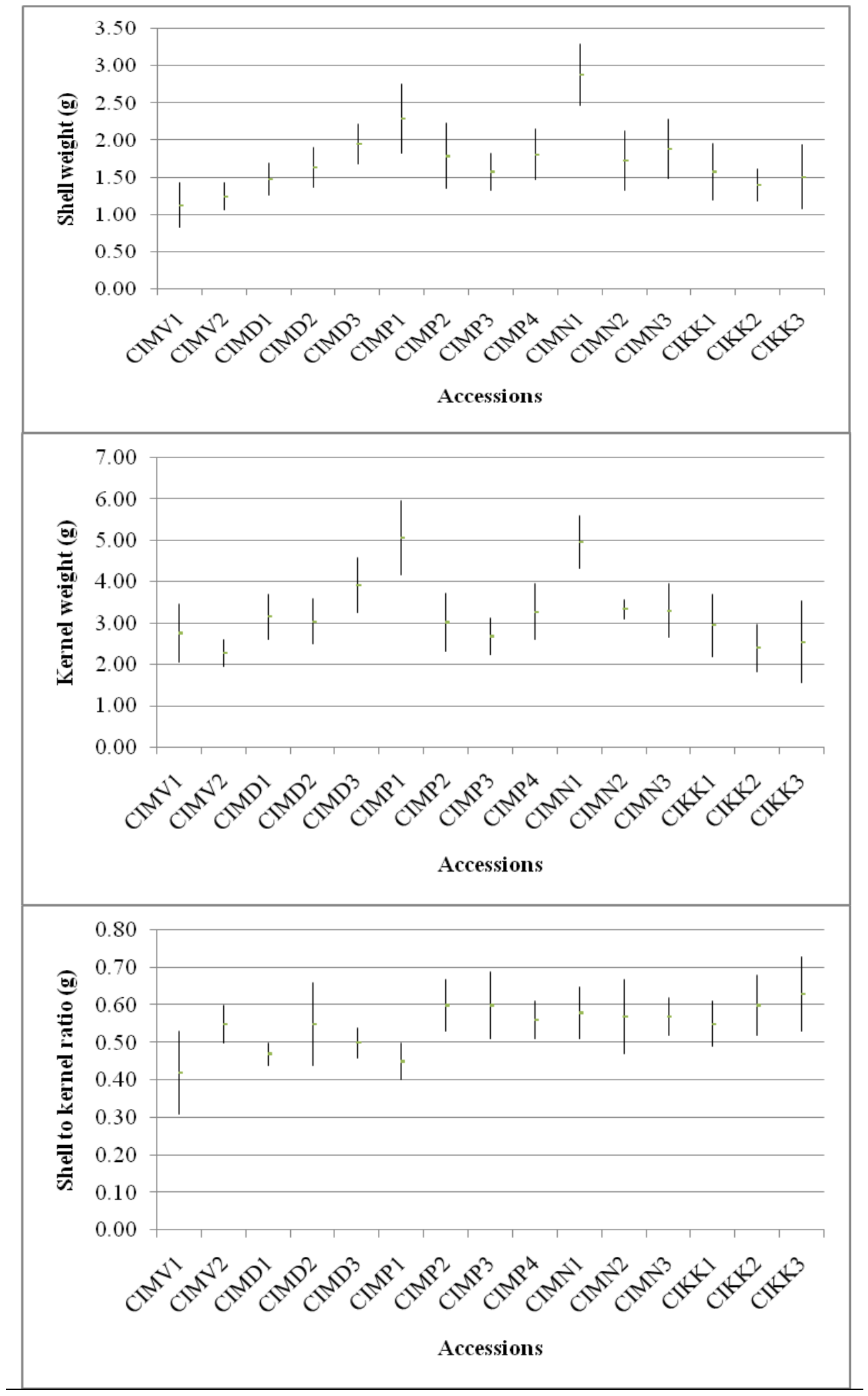


Such kind of seed source variation was also recorded by Shinde et al., (2012) using 21 genotypes of Maharashtra and Palanikumaran et al., (2015) using 30 provenances of $C$. inophyllum in Southern India.

It is concluded that seeds collected from 15 different seed sources of $C$. inophyllum in coastal lines of Konkan regions showed greater variation in most of the fruit and seed traits. Seed sources such as $\mathrm{CIMD}_{3}, \mathrm{CIMP}_{1}$, $\mathrm{CIMP}_{4}, \mathrm{CIMN}_{1}, \mathrm{CIMN}_{2}$ and $\mathrm{CIMN}_{3}$ resulted in bigger sized seeds than nine other sources. Therefore, these sources may be used for improvement programme as well as to raise quality seedlings in large quantity.

\section{Acknowledgements}

Authors are thankful to Revenue Department and Forest Department of Maharashtra and Karnataka for giving permission to collect seed materials for conducting experiments. Navsari Agricultural University, Navsari is acknowledged for support and permission to carry out this experiment in the campus. Authors are also thankful to Mr. Prashant Kamble, M.Sc. Scholar of Dr. B.S. K. K. V., Dapoli for his support in field studies especially in locating the natural populations of $C$. inophyllum in Maharashtra region.

\section{References}

Agarwal, A.K. 2007. Biofuels (alcohols and biodiesel) applications as fuels for internal combustion engines. Progress in Energy and Combustion Sciences, 33(3): 233-271.

Bahadur, R. and Hooda, M.S. 1995. Genetic variability and correlation studies for some pod and seed traits in Khejri (Prosopis cineraria (L.) Druce). Indian Journal of Forest, 18(2): 161-164.

Bhat, G.S. and Chauhan, P.S. 2002. Provenance variation in seed and seedling traits of Albizzia lebbeck Benth. Journal of Tree Sciences, 21: 5257.

Chavan, S.B., Kumbhar, R.R. and Deshmukh, R.B. 2013. Calophyllum inophyllum Linn. ("honne") oil: A source for biodiesel production. Research Journal of Chemical Sciences, 3(11): 24-31.

Friday, J.B. and Okano, D. 2006. Calophyllum inophyllum (kamani) species profiles for Pacific Island agroforestry, Traditional Tree Initiative, Hawaii, (cited from http//.traditional tree.org).

Gunaga, R.P. 2011. Influence of seed size on seed germination and seedling vigour in Calophyllum inophyllum: an important multipurpose tree of coastal region. Journal of Indian Society of Coastal Agricultural Research, 29(2): 35-38.

Hathurusingha, S., Nanjappa, A., Wijesekara, K. and Midmore, D. 2011. Reproductive phenology of Calophyllum inophyllum in Yeppon, Australia and Meegoda Western Province, Sri Lanka. Journal of Forestry Research, 22(4): 615- 619.

Kaushik, N., Kumar S., Kumar, K., Beniwal, R.S. and Roy, S. 2007. Genetic variability and association studies in pod and seed traits of Pongamia pinnata (L.) Pierre in Haryana, India. Genetic Resource Crop Evolution, 54: 18271832.

Midgley, S. 1996. Seed collection strategies in a changing world. In: IUFRO: Innovations in tropical tree seed technology. Proceedings of the IUFRO Symposium of the Project Group P.2.04.00, 'Seed Problems'. Arusha, Tanzania. 1995.

Palanikumaran, B., Parthiban, K.T., Sekar, I., Umarani, R. and Amirtham, D. 2015. Variability studies for seed and seedling traits in Undi (Calophyllum Inophyllum L.) from different zones of south India. 
Journal of Plant Science and Research, 2(2): 124-128.

Pavithra, H.R., Gowda, B., Prasanna, K.T., Shivanna, M.B. 2013. Pod and seed traits in Candidate Plus Trees of Pongamia pinnata (L.) Pierre from Southern Peninsular India in relation to provenance variation and genetic variability. Journal of Crop Science and Biotectnology, 16(2): 131-142.

Rahul, S. 2016. Provenance variation for seed traits, germination, seedling vigour and oil content in Calophyllum inophyllum
Linn. M.Sc. Forestry thesis, Navsari Agricultural University, Navsari, India. Pp. $78+x i$.

Schmidt, L. 2000. Guide to Handling of Tropical and Subtropical Forest Seed. Pp. 6-7.

Shinde, P.P., Rane, A.D., Bhave, S.G., Gunaga, R.P. and Narkhede, S.S. 2012. Variability and genotype selection in Calophyllum inophyllum for quality fruit yield in the central west coast of India. Journal of Tree Sciences, 31(1\&2): 8-14.

\section{How to cite this article:}

Rahul Sreekumar and Rajesh P. Gunaga. 2017. Variation in Fruit and Seed Traits among Different Seed Sources of Calophyllum inophyllum L. Collected from Coastal Regions of Konkan, India. Int.J.Curr.Microbiol.App.Sci. 6(12): 441-448. doi: https://doi.org/10.20546/ijcmas.2017.612.054 